\title{
ARTIFICIAL AGING COMPARISON BETWEEN HIGH SOLID AND THREE LAYER PAINT SYSTEM
}

\author{
Ercüment Şakir GÜREL ${ }^{*}$ (D), Armağan ALTINIŞIK ${ }^{1}$ D, Faruk YILMAZ1 ${ }^{1}$ \\ ${ }^{1}$ Tofaş, Türk Otomobil Fabrikası A.Ş., Turkey, Bursa,
}

\begin{abstract}
Due to the usage of the conversional high solid topcoat paint cycle and three-layer paint cycle system on vehicle body high bake aesthetical painting process, there is so much controversial opinion on last decade about aging performance of these two-painting system. Generally, vehicle manufacturers prefer three-layer aesthetical paint cycle on vehicle body. This cycle is formed as respectively primer layer, coloured basecoat layer and transparent clearcoat layer.

High solid systems are generally applied by vehicle manufacturers to obtain value optimization when compared with three-layer paint system. On the other hand, UV and atmospheric aging resistance is not competitive as three-layer paint system. This is the main focussing point of manufacturers choice.

In this study, these two paint systems artificial aging resistance (SAE J2527-2500 kj) compared. In order to understand situation in numeric system, the gloss and colour values were measured. In this comparison, solid white colour was chosen due to its easiness to obtain for both paint cycle system and being pure colour.

At the end of study it was seen that until $60 \%$ percent of test, colour \& gloss properties behave not durable and there are main changings as colour and gloss values.
\end{abstract}

Keywords: Primer, Basecoat, Clearcoat, Artificial Aging 


\section{YÜKSEK KATI ORANLI SONKAT VE ÜÇ KATMANLI DÖNGÜ SİSTEMLERİ ARASINDA HIZLANDIRILMIŞ YAŞLANDIRMA DAYANIMI KARŞILAŞTIRILMASI}

\section{$\ddot{O} z$}

Yüksek firınlamalı olarak kullanılan yüksek katı oranlı Topcoat ve üç katmanlı döngü estetik boya uygulama proseslerinin yaşlanma performansları arasında son 10 yılda birçok karşıt görüş oluşmuştur. Genelde otomobil üreticileri üç katmanlı boya döngüsünü tercih ederler. Bu uygulama döngüsü sırasıyla, primer katmanı, bazkat katmanı ve transparant vernik katmanı olarak şekillenir. Yüksek katı oranlı sistemler ise üç katmanlı boya döngüsü ile karşılaştırıldıklarında, genel olarak otomobil üreticileri tarafından maliyet iyileştirmesi amaçlı uygulanmaktadırlar. Diğer yandan bu sistemlerin UV ve atmosferik yaşlanma dayanımları üç katmanlı döngü sistemleri kadar rekabetçi değillerdir. Bu özellik ise otomobil üreticilerinin seçimlerinin ana odak noktasıdır.

$\mathrm{Bu}$ çalışmada, iki boya uygulama sistemi yaşlandırma dayanımı (SAE J2527-2500 kj) karşılaştırılmıştır. Karşılaştırmayı numerize etmek için renk ve parlaklık değerleri ölçülmüştür. Bu karşılaştırmada iki uygulama sistemiyle de elde edilmesi kolay ve saf bir renk olmasında dolayı bu çalışmada beyaz renk esas alınmıştır.

Çalışmanın sonunda ise \%60 tamamlanma yüzdesine kadar renk ve parlaklık değerlerinin değerlerin değiştiği ve bu periyotta stabil kalmadıkları görülmüştür.

Keywords: Primer, Bazkat, Vernik, Hızlandırılmış Yaşlandırma

\section{INTRODUCTION}

Main focus of this study understand every steps of artificial aging on both systems as numerical explanation using gloss and colour mesurement Also step by step control approach in this study simplifies prediction of test results.

Generally vehicle manufacturers demand specific aesthetical requirements from body paintings [1]. These requirements could be classified as two main focus;

Aesthetical Requirements;

$>$ Gloss measurement,

$>$ Colour measurement, 
$>$ Wave scan (orange peel) requirements,

Visual inspections,

Durability Requirements During Service Time

Adhesion,

$>$ Humidity resistance,

$>$ Aesthetical durability,

$>$ Stone stroke resistance,

$>$ Water resistance,

$>$ Chemical resistance,

$>$ Thermal shock resistance.

Vehicle manufacturers can obtain this requirement with applying high solid paint cycle system or three-layer paint cycle system. On the other hand high solid system's innovativeness, vehicle manufacturers apply three-layer paint cycle system. Both systems shown in Figure 1 as cross sectional image. This both systems are high bake systems [1-2] Due to competitions on automotive market validation in this study is needed.

Advantage of this cycle is every layer has own main function and additional cycle function. Primer layer has filling of surface, excellent adhesion function. Basecoat and clearcoat layers have aesthetical appearance, UV and atmospheric resistance functions. Also all layers should provide excellent adhesion function between layers to keep full cycle intacting in service life. On the other hand, high solid topcoat paint cycle is formed as respectively primer layer and coloured topcoat layer. In this cycle, primer's function is same with three-layer cycle system. But topcoat layer's functions has to provide an excellent UV and atmospheric aging resistance and aesthetical visuality with one layer. Also this cycle system could only serve in solid colours because solid ratio couldn't provide good metallic orientation and visuality where aesthetical focus has increased [3-4]. Figure 1 shows related layers about both paint systems. 
a.

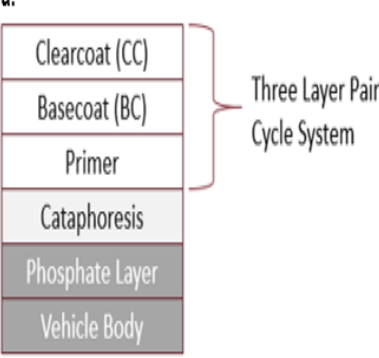

b.

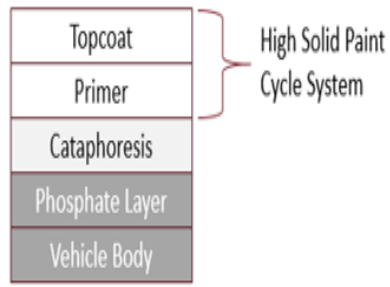

Figure 1. a) Three Layer Paint Cycle System b) High Solid Paint Cycle System

\section{GENERAL}

Due to increased aesthetical expectation and durability demands of vehicle customers, vehicle manufacturers are increased atmospheric aging requirements, in order to estimate durability of vehicle aesthetical paint. Nowadays SAE J2527 standard has been widely used by so many manufacturers. However, recently ASTM 7869 standard has become well liked to obtain more simulated results [5].

With increased durability demand, three-layer paint cycle system has become more well liked and convenient to provide high level of aesthetical durability. The technological speed of respond to the demands also makes this choice as perfectly preferable. For this reason, manufacturers prefers three cycle paint system rather than high solid system [3].

In order to understand durability of paint system both numerical colour and visual analysis are main focus points. Manufacturers generally decide with results of both analysis.

In this study, two paint cycle system's artificial and accelerated aging results were compared for the aspect of visual changing, gloss loss and colour changing analysis [4-5]. For measurements and artificial aging tests, TOFAŞ Türk Otomobil Fabrikası A.Ş. Material Engineering laboratory infrastructures and professional experince has been used.

Artificial and accelerated aging tests were performed with Atlas CI 4000 measurement device. SAE J2527 standard was applied as the measurement test procedure. Boro/boro filter was used to simulate daylight. The details of the test procedure were summarized in Table 1. 
Table 1. SAE J 2527 Standart's Cycle

\begin{tabular}{|c|c|c|c|c|c|c|}
\hline Step \# & $\begin{array}{c}\text { Irradiation } \\
(\mathrm{w} / \mathrm{m} 2 @ 340 \mathrm{~nm})\end{array}$ & $\begin{array}{c}\text { Duration } \\
(\mathrm{Min})\end{array}$ & Water Spray & $\begin{array}{c}\text { Chamber } \\
\text { Humidity } \\
(\% \mathrm{rh})\end{array}$ & $\begin{array}{c}\text { Chamber } \\
\text { Temperature } \\
\left({ }^{\circ} \mathrm{C}\right)\end{array}$ & $\begin{array}{c}\text { Black Panel } \\
\text { Temperature } \\
\left({ }^{\mathrm{C}} \mathrm{C}\right)\end{array}$ \\
\hline 1 & 0,55 & 40 & Off & 50 & 47 & 70 \\
\hline 2 & 0,55 & 20 & Front & 95 & 47 & 70 \\
\hline 3 & 0,55 & 60 & Off & 50 & 47 & 70 \\
\hline 4 & 0 & 60 & Fornt/Back & 95 & 38 & 38 \\
\hline
\end{tabular}

\subsection{Colour and Gloss Measurements}

Measurements were performed with gloss and colour measurement devices. Gloss controls were made with Erichsen gloss measurement device. $20^{\circ}$ and $60^{\circ}$ were chosen as gloss angles, these angles are highly suggested for mid-high gloss surfaces [4-6]. Figure 2 shows gloss angles simple explanation.

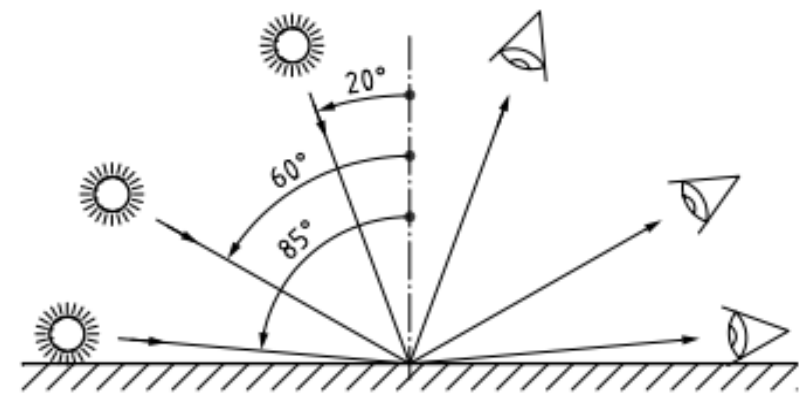

Figure 2. Gloss Measurement Angles

CIE L. a. b. colour space was chosen in order to analyse colour changing. Colour controls were made with X-Rite MA-98 spectrophotometer. $15^{\circ}, 25^{\circ}, 45^{\circ}, 75^{\circ}$ and $110^{\circ}$ (Fig. 4)were chosen [1] as angle of colour to understand colour differences in different aspects of customer [5-7]. Figure 3 shows angles and Figure 4 shows L. a. b. 3-D colour space. 


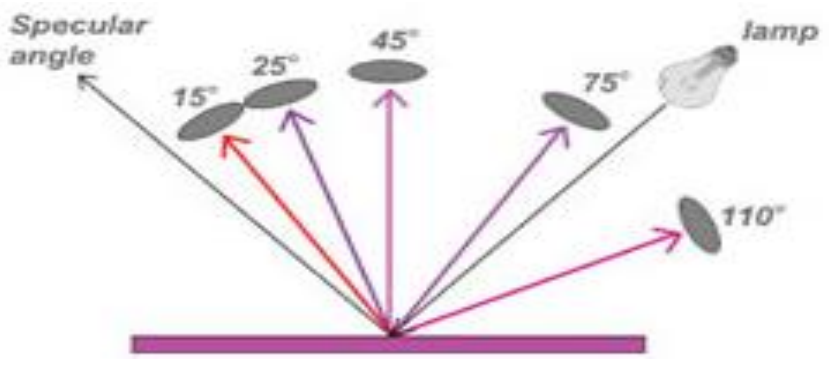

Figure 3. Colour Measurement Angles

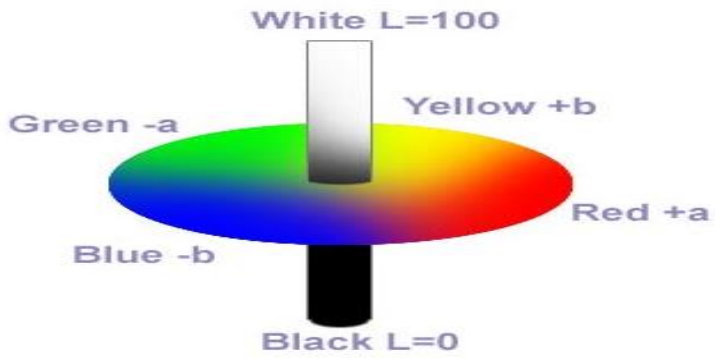

Figure 4. CIE L. a. b. Colour Space

\subsection{Sample Preparation and Data Collection}

Both system samples have been prepared in laboratory condition as indicated in supplier technical data sheet. Same primer material was used for samples to avoid any variability caused by this material [1-4]. In order to avoid this kind of variability, systematic approach were used on Table 2

Table 2. Sample Preparation Details

\begin{tabular}{|c|c|c|c|c|c|c|c|c|}
\hline \multirow{3}{*}{ System } & \multicolumn{8}{|c|}{ Layers } \\
\hline & \multirow{2}{*}{ Primer } & \multicolumn{3}{|c|}{ Basecoat } & \multicolumn{4}{|c|}{ Clearcoat } \\
\hline & & Application & Thickness & Flash-off & Application & Thickness & Flash-off & Cuning Oven \\
\hline High Solid & $P P G$ & Robotic & TDS & TDS & Robotic & TDS & TDS & Thermograph Curve as TDS \\
\hline Three Layer & PPG & & - & & Robotic & TDS & TDS & Thermograph Curve as TDS \\
\hline
\end{tabular}


In order to understand the differences in each cycle, the controls and measurements were planned and performed in six different periods shown in Table 3.

Table 3. Data Collection periods

\begin{tabular}{|c|c|c|}
\hline \multirow{2}{*}{ Phase } & \multicolumn{2}{|c|}{ Control } \\
\cline { 2 - 3 } & High Solid Paint Cycle System & Three Layer Paint Cycle System \\
\hline $0 \mathrm{Kj}$ & Colour \& Gloss Measurement & Colour \& Gloss Measurement \\
\hline $500 \mathrm{kj}$ & Colour \& Gloss Measurement & Colour \& Gloss Measurement \\
\hline $1000 \mathrm{kj}$ & Colour \& Gloss Measurement & Colour \& Gloss Measurement \\
\hline $1500 \mathrm{Kj}$ & Colour \& Gloss Measurement & Colour \& Gloss Measurement \\
\hline $2000 \mathrm{Kj}$ & Colour \& Gloss Measurement & Colour \& Gloss Measurement \\
\hline $2500 \mathrm{Kj}$ & Colour \& Gloss Measurement & Colour \& Gloss Measurement \\
\hline
\end{tabular}

\section{RESULTS}

\subsection{Gloss Retention after Aging Test}

After aging test, panels are conditioned in laboratory condition for six hours. Then, $20^{\circ}$ and $60^{\circ}$ gloss controls were performed. The result at $60^{\circ}$ gloss is shown below Figure 5 as decrease amount. Also gloss retention ratios are given in Figure 6.

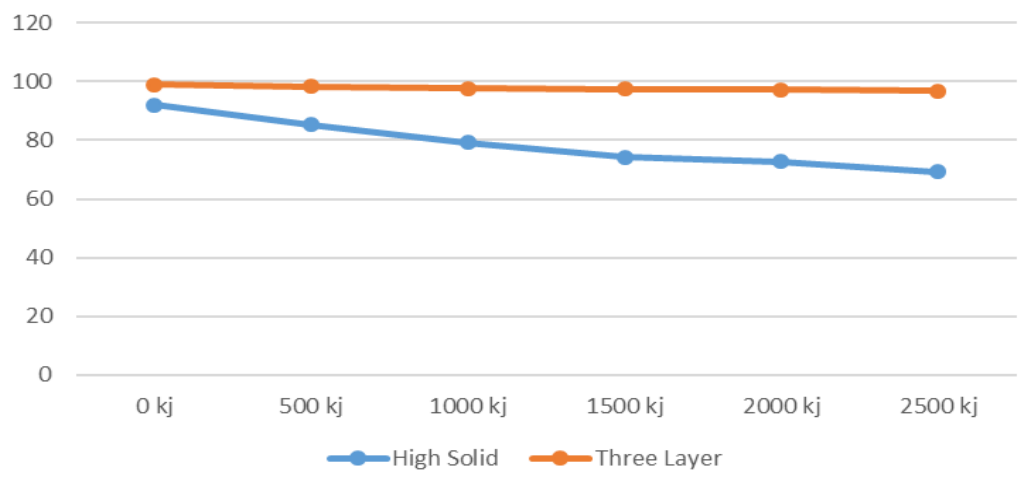

Figure 5. $60^{\circ}$ Gloss Changing of Paint Systems 
Araştırma

DOI: 10.34186/klujes.626926

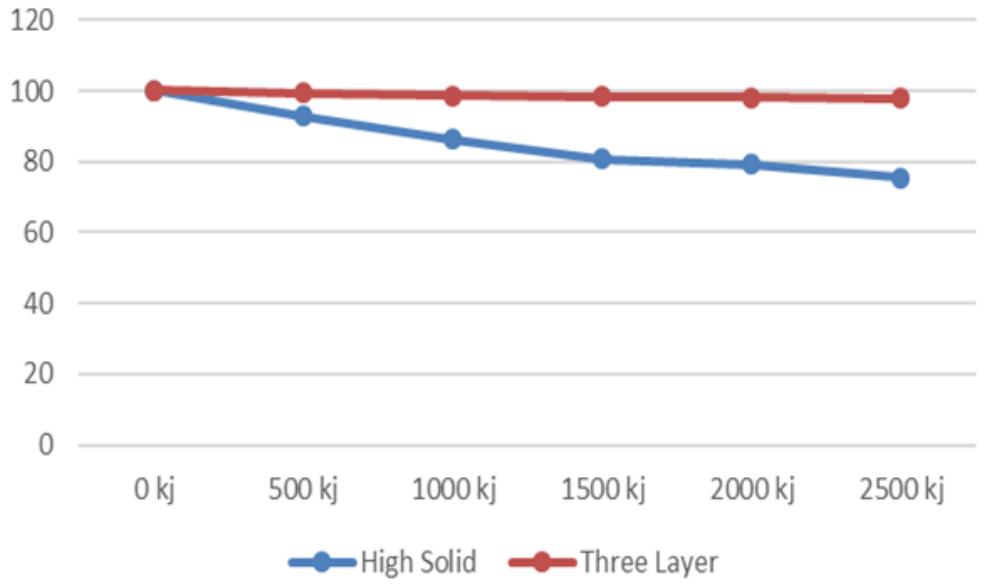

Figure 6. $60^{\circ}$ Gloss Retention Comparison

$60^{\circ}$ gloss measurements show that (as seen in Figure 7 and 8) the loss ratio is about $20 \%$ for high solid paint cycle system that is lower than $5 \%$ for three-layer paint cycle system. The gloss decrease ratio after $1500 \mathrm{~kJ}$ test cycle is significantly better than early test cycles especially for high solid paint cycle system. The test results will not change noticeably after this test completion ratio. The gloss values and related retention ratios at $20^{\circ}$ are shown in Figure 9 as decrease amout and Figure 10 as gloss retention ratio, respectively.

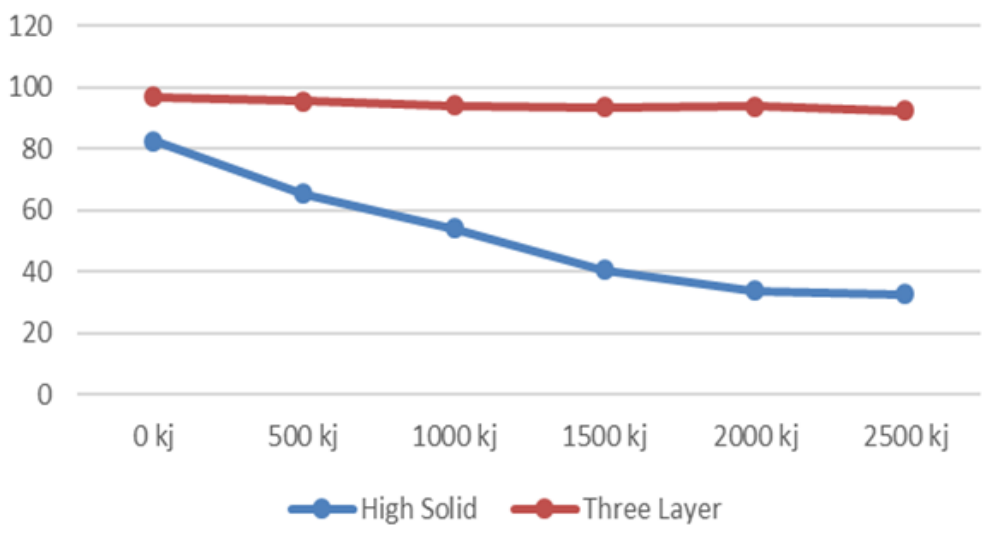

Figure 7. $20^{\circ}$ Gloss Changing of Paint Systems 


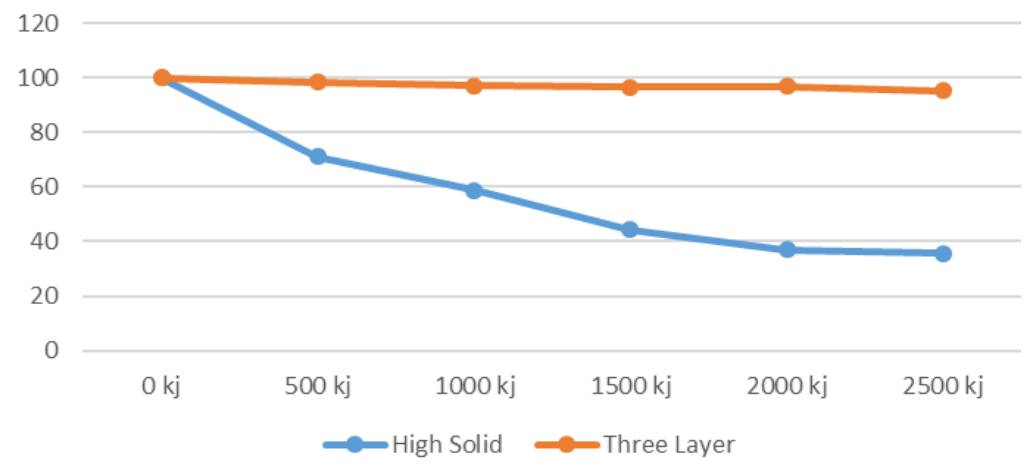

Figure 8. $20^{\circ}$ Gloss Retention Comparison

$20^{\circ}$ gloss changes is not in same way with $60^{\circ}$ gloss changings. $20^{\circ}$ gloss measurements, Figure 7 and Figure 8 show that loss ratio is about 60 percents for High solid paint cycle system, lower than 5 percents for three layer paint cycle system.

When all gloss datas were analyzed, first $1500 \mathrm{kj}$ test duration gloss decrease ration is significantly better than early durations gloss loss especially for high solid paint cycle system. In this test completion ratio we can comment that test result will not change excessively after this ratio but vehicle manufacturers requirements acceptance criteria is very important in this point especially for high solid paint cycle system due to high gloss loss. When $60^{\circ}$ and $20^{\circ}$ gloss loss differences show that $20^{\circ}$ gloss is more compatible than $60^{\circ}$ gloss in order to understand differences in changings

\subsection{Colour Changings after Aging Test}

After aging test, panels are conditioned in laboratory condition for 6 hours. Then $15^{\circ}-25^{\circ}-45^{\circ}-$ $75^{\circ}-110^{\circ}$ colour measurement controls were made. Values were shown in Figure 9, 10, 11, 12, 13 respectively as changing of $\mathrm{L}, \mathrm{a}, \mathrm{b}$, values in every $500 \mathrm{kj}$. 


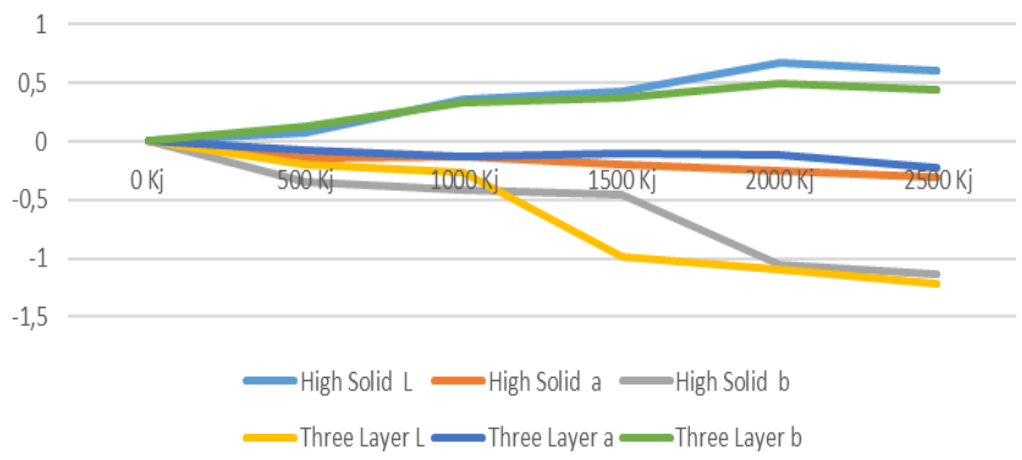

Figure 9. $15^{\circ}$ L. a. b. Colour Changings Graph.

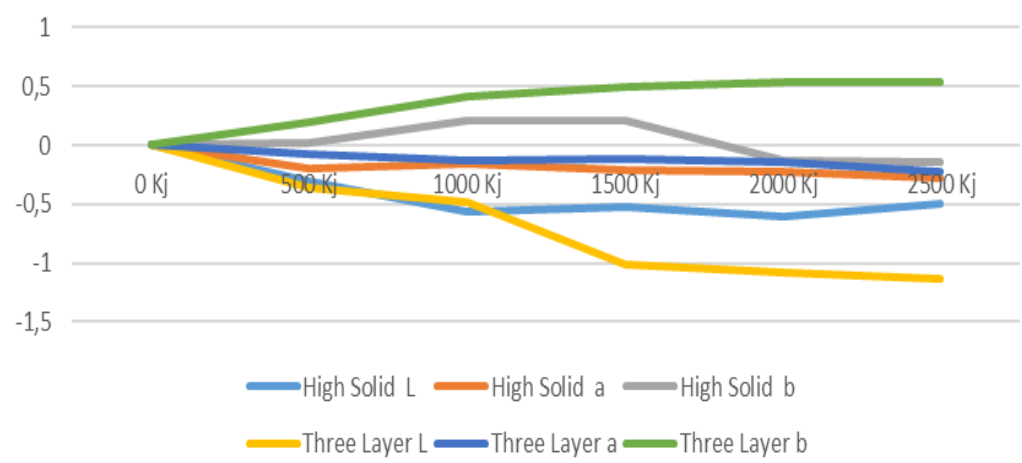

Figure 10. $25^{\circ}$ L. a. b. Colour Changings Graph.

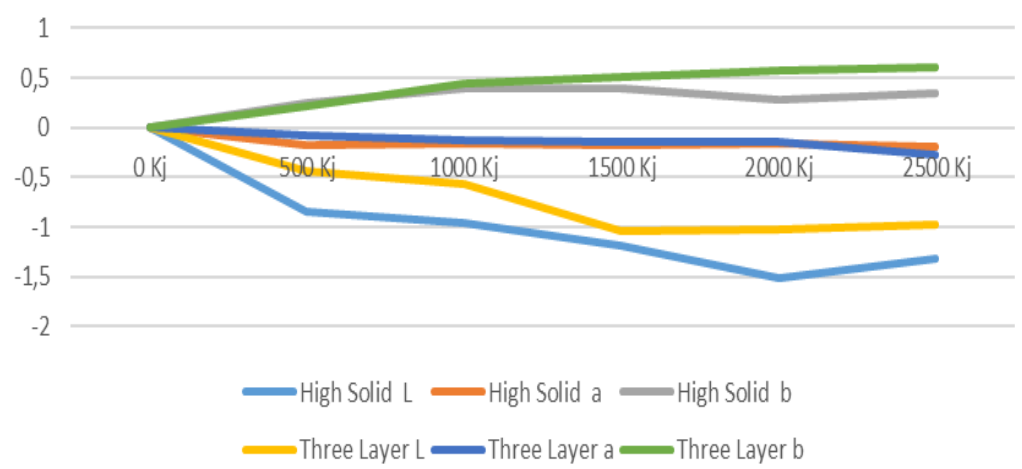

Figure 11. $45^{\circ}$ L. a. b. Colour Changings Graph. 
Araştırma

DOI: $10.34186 /$ klujes. 626926

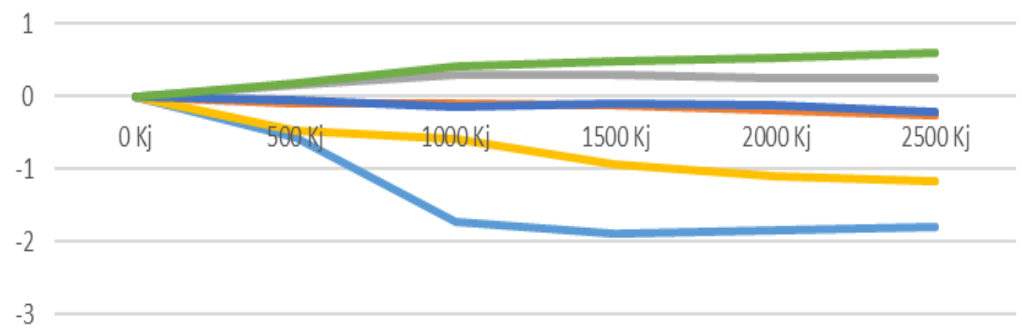

High Solid L $\longrightarrow$ High Solid a High Solid b

Three Layer $\mathrm{L} \longrightarrow$ Three Layer a —Three Layer $\mathrm{b}$

Figure $12.75^{\circ}$ L. a. b. Colour Changings Graph.

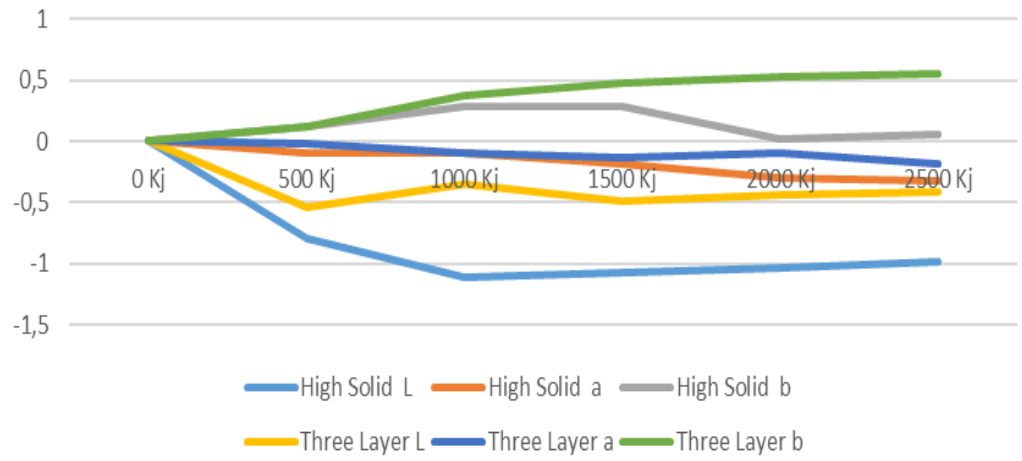

Figure 13. $110^{\circ}$ L. a. b. Colour Changings Graph.

$15^{\circ}$ colour changings in Figure 9 show that $b$ values are changed in different way and according to Figure 4 this increase commented as high solid paint cycle system are bluished in the contrary high solid paint cycle system is slightly yellowished. The decrease on L values are especially in three layer paint cycle system results, can be commented as paint cycle darkened. But when samples were inspected visually this effects seen invisible.

On the other angles, decrease of L values that shown in Figure 10, 11, 12, 13 higher for High Solid Paint Cycle. Also all angles result shows that Three Layer Paint System's b values has increased more and we can comment that this paint cycle shows less resistance to yellowishing. 
When all colour changing datas were analysed, first $1500 \mathrm{kj}$ test duration, colour deviations were stayed stable. In this test completion ratio we can comment that test result will not change excessively after this ratio as same in gloss values. This point of test give a chance to comment that values of both systems didn't change significantly for all angles.

\section{CONCLUSION}

In this study High Solid and Three Layer Paint Cycle System's aging performances analysed as aspect of gloss \& colour values. Results of both systems were compared as numerically.

As summary both high solid system and three layer system have no great differences after SAE $\mathrm{J} 2527-2500 \mathrm{kj}$ aging test as aspect of colour. This general colour result was commented with only $15^{\circ}$ angle results differences neglected due to thinking all angles as an entire evaluation system and $15^{\circ}$ angle results couldn't effect other angles as shown in Figure 10,11,12,13.

On the other hand, three layer paint cycle system has a very good resistance to gloss loss criteria. In contrary, high solid system's gloss level was decreased to very low gloss levels. This result give very important feedback about vehicle paint durability. Also both systems result give vehicle manufacturers to estimate tests final result at $1500 \mathrm{kj}$ test duration as mentioned above. Experimental study shows us above mentioned results needs to be taken in to consideration by manufacturer during part design and process selection phases.

\section{REFERENCES}

[1] Streitberger N.J., Dossel K.F., Automotive Paints and Coatings. John Wiley and Sons, Inc. 2005, 2nd edn, 2008.

[2] Beck, E., European Coatings Journal, 4, 32, 2006.

[3] Sing, L.P., Nadal, M.E., Knight, M.E., Marx, E., Laurenti, B., Journal of Coatings Technology, 74(932), 55, 2002.

[4] Osterhold, M., Wagner, G., Progress in Organic Coatings, 45, 365, 2002. 
DOI: $10.34186 /$ klujes. 626926
Gürel vd./Kırklareli University Journal of Engineering and Science 7-1(2021) 21-33

Geliş Tarihi:30.09.2021～Kabul Tarihi:31.12.2020

[5] ASTM Standart D 7869:17, Standard Practice for Xenon Arc Exposure Test with Enhanced Light and Water Exposure for Transportation Coatings, Annual Book os ASTM Standarts, Vol. 06.01, American Society for Testing and Materials, Philadelphia, 2017.

[6] Billmeyer, F.W. Jr., Saltzmann, M., Principles of Color Technology, 2nd edn, John Wiley \& Sons, Ltd, NewYork, 1981.

[7] DIN EN ISO 2813: 1999-Paints and Varnishes - Measurement of Specular Gloss of NonMetallic Paint Films at 20, 60 and 85, International Organization for Standardization, 1999. 